\title{
CHANGE DETECTION IN MOSUL DAM LAKE, NORTH OF IRAQ USING REMOTE SENSING AND GIS TECHNIQUES
}

\author{
M.A. Al-Obaidi ${ }^{1}$ \\ Researcher \\ Y.K.AL-Timimi \\ Assist. Prof.
}

${ }^{1}$ Dept. Space and Communications -Geophysics Research Center- Ministry of Science and Technology

${ }^{2}$ Dept. of Atmospheric Sci. Coll. of Sci. Mustansiriyah University

1 Mervatali2005@gmail.com

2yaseen.altimimi.atmsc@uomustansiriyah.edu.iq

\section{ABSTRACT}

This study was aimed to demonstrate the spatial changes of Mosul Lake using change detection Techniques. Water bodies, an integral part of the Earth's hydrological cycle, such as rivers, ponds, lakes, wetlands, and reservoirs, have a major effect on climate change and global warming. one of the most imperative vital activities in Iraq for the administration of its water resources is Mosul Dam Lake. The lake has changed in the water surface due to the severe anthropogenic activities, climate change, the monthly inflows received from the Tigris River, and the controlling of water imports by neighboring countries, and the territorial policy. Remote sensing techniques and Geographic Information System ArcGIS 10.3 software were used in the present study for processing the images and managing the database of each image were downloaded from the united states geological survey(USGS). Spectral Water indices, includes Normalized Difference Water Index (NDWI) and unsupervised classification were used to extracting water bodies and computing water area, the images difference technology was used to detect a different image and capture changes area for 20 years, the method has been applied to subsets of the Landsat series images that acquired during April in 2000, 2005, 2010,2015 and 2020. The results showed that there is an increase in the area of Mosul dam lake from its original area in 1986 which was $244 \mathrm{~km}^{2}$ in a rate of $(15.1,31.14,13.11$, and $20.9) \%$ for periods $(200,2005,2015$, and 2020$)$ respectively, and a decrease in water area with a rate of $7.78 \%$ for period 2010 , that means the water surface area fluctuated over the period given, increasing and decreasing in the water surface. the minimum water surface area was recorded in 2010 of about $225 \mathrm{~km}^{2}$, whereas, the maximum area of the lake was found to be $320 \mathrm{~km}^{2}$ in 2005 . the total average increasing and decreasing change detection were 25.4550174 and $19.7851824 \mathrm{~km}^{2}$ respectively.

Keywords: Normalized difference water index, image differencing, surface water, landsat, satellite images.

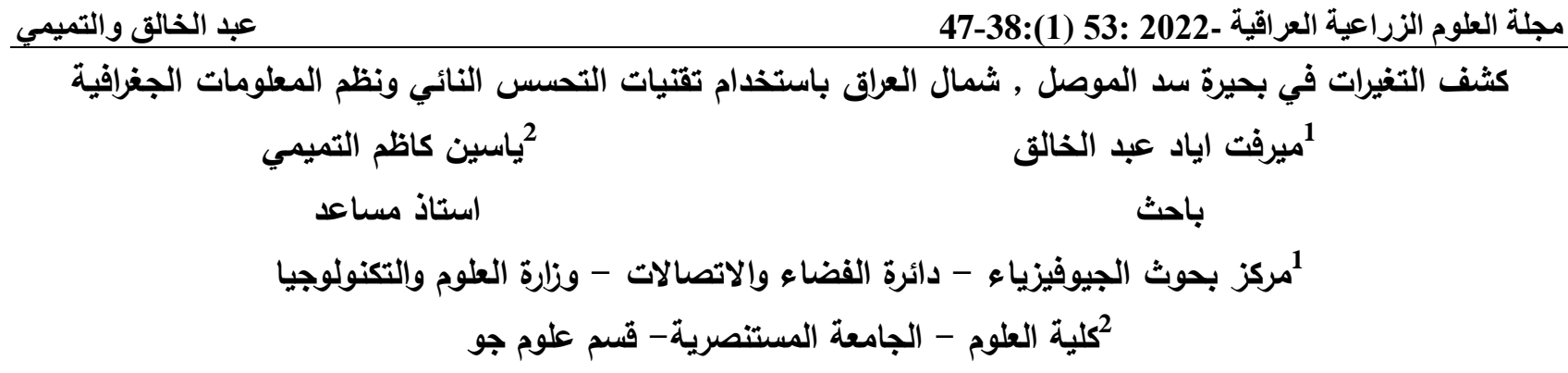

هدفت هذه الدراسة إلى توضيح التغيرات المكانية في بحيرة الموصل باستخدام تقتيات الكشف عن التغايير. المسطحات المائية ، وهي جزء لا يتجزأ من

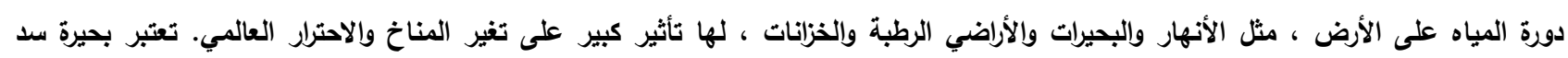

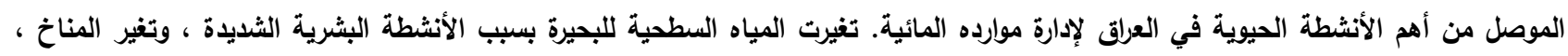

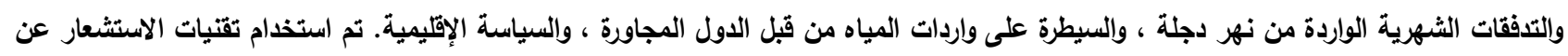

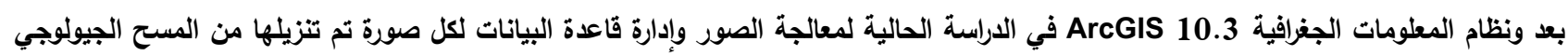
للولايات المتحدة (USGS) تم استخدام مؤشرات المياه الطيفية بما في ذلك مؤثر الماء الفروق الطبيعي(NDWI) والتصنيف غير المبردة المراقب لاستخراج المسطحات المائية وحساب مساحة المياه السطية ، وتم استخدام تقنية اختلاف الصور لاكتشاف التغيرات افي الصور والتقاط منطقة التغييرات لمات لمدة التهات 20 عامًا ، وقد تم تطبيق الطريقة على مجموعة من صور سلسلة لاندسات التي تم الحصول عليها خلال شهز أبريل في أعوام 2000 و 2005 و 2005

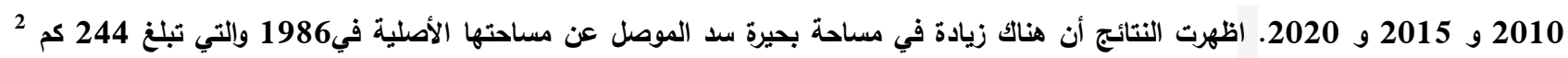

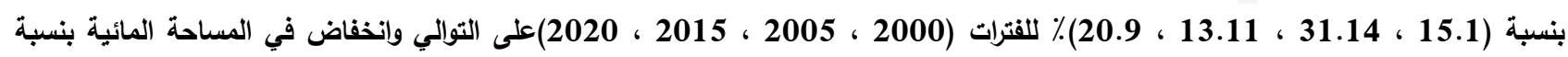
78 \% 7.78 للفترة 2010 ، وهذا يعني أن المساحة السطحية المائية للبحيرة متذبذبة خلال الفترة المعطاة ، تزداد وتقل في المساحة المائية. تم تسجيل ،

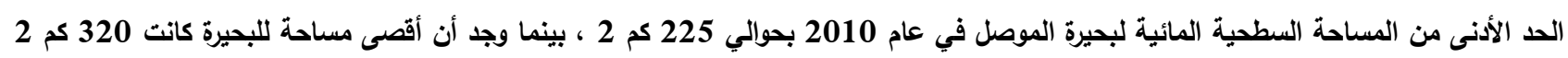
في عام 2005. وكان المتوسط الكلي للكثف عن التغير المتزايد والمتناقص 25.4550174 و 19.7851824 كم 2 على التوالي. الكلمات المفتاحية: معامل فروق الماء الطبيعي ,اختلاف الصور ,المياه السطحية ,لاندسات ,صور اقمار صناعية. 


\section{INTRODUCTION}

Typically, Surface water bodies are dynamic in nature as they decrease, increase, and change their appearance or course of the stream with time, due to various natural and human-instigated factors(21). These changes usually cause serious consequences in extreme cases, It can cause floods and droughts; Therefore, it is necessary to distinguish the presence of surface water, extract its extent, evaluate and Calculate the quantity of its volume, and monitor its dynamics(20). Geographically, in the world's driest belt, Iraq is situated (4), This implies that Iraqi agriculture relies on surface and groundwater resources to provide the irrigation water required for agricultural stability(36). These resources are restricted and the greater part of them are imparted to different countries neighboring Iraq, also have faced a lot of threats and damages that caused to decrease the water supply of the country. one of the biggest artificial reservoir in Iraq $(26,28)$, Mosul Dam Lake, which was selected as a case study, is one of the most important Strategic Services Projects in Iraq which supporting the water interest of Mosul, Baghdad, and different urban areas, also provide water for an irrigation project called [North Al-Jazira Irrigation project] (26). The definition of water indices is a recent technique introduced for the recognition of water bodies through changes. Mathematical models improve the water signals in images collected from visible/near-infrared scanning sensors for a given pixel(10). Two bands usually specify these models from the visible (green) and near-infrared portions of the spectrum, When Green and NIR refer to the reflection in the green and near-infrared spectra respectively (14). Among the common water indices are the (NDWI) and the modified normalized difference water index (MNDWI) both of them have been successfully used to delineate surface water area information $(12,23)$. for deeper parts of the water surface, NDWI has a superior outcome, while for shallower parts has bad. In this manner, the utilization of the (NDWI) approach enhance water's reflectance features by reducing the low reflectance of Near Infrared (NIR) and improving the reflectance in green wavelength $(25,35)$. Many studies focused on using remote sensing and GIS techniques to detect the changes in Landsat images, these studies are:

Mahir Mahmod H. evaluated water surface area for a period from (1984-2019) The results indicated that the water layer suffered a pattern of changes concerning the water of the surface area(24).

Issa E. Issa calculated the Storage capacity and water surface area of the Mosul reservoir used two satellite images in 1986 and 2011 by The Triangular Irregular Network TIN maps(17).

Khattab, M.F.O. The (NDWI) was used to automatically delineate coastline then computed the area and volume values of the Mosul Dam Lake applying the TIN model from satellite images during 2011. (28).

This study was aimed to demonstrate the spatial changes of Mosul dam Lake using change detection in the period from 20002020 utilizing multi-temporal Landsat Thematic mapper 5, Enhance Thematic mapper +7 , and Operational Land Imager 8 data.

\section{MATERIALS AND METHODS \\ Description of the study area}

Mosul Dam is one of the large dams in the world, the second greatest dam in the Middle East, and the largest dam in Iraq, due to the capacity of its reservoir (2). at a maximum operation level with a maximum storage volume and a maximum water depth, The water surface area of its reservoir is $380 \mathrm{~km}^{2}$ the length is about $45 \mathrm{~km}$ and the width ranges between 2 and $14 \mathrm{~km}(22)$. Mosul dam lake Figure 1; is an artificial reservoir located between latitude $\left(36^{\circ} 36^{\prime} \mathrm{N}-36^{\circ} 50^{\prime} \mathrm{N}\right)$ and longitude $\left(42^{\circ} 27^{\prime} \mathrm{E}-42^{\circ} 58^{\prime} \mathrm{E}\right)$, build on Tigris river in northern Iraq approximately 50 kilometers northwest of Mosul city and 80 kilometers from the Syrian and Turkish borders, also is about $500 \mathrm{~km}$ on a straight line distance to the north from Baghdad (27) started operating in 1986. Typically, The climate area may be regarded as being similar to a Mediterranean climate, is hot and dry during the summer, while cold and rainy during winter with occasional snowfall taking place in the mountainous region(16), The average monthly temperatures range between $6^{\circ} \mathrm{C}$ in January to $34^{\circ} \mathrm{C}$ in July, but the 
temperatures decrease toward north regions of Iraq (18), the annual average of wind speed in the northern regions was low about $2.7 \mathrm{~m} / \mathrm{s}$ compared to the middle and southern regions(3), while (19) splits Iraq into three climatic zones according to the rainfall factor, the study area in Arid and Semi-Arid Zone where the annual rainfall above $400 \mathrm{~mm}$. In April and May, a most seasonal discharge occurs, whereas there's less discharge in October and September. Published research has concluded that the Ilisu Dam project would significantly reduce the inflow to the reservoir of the Mosul Dam. (9,34). The lake has changed in the water surface due to the severe Human activities, climate change, and also the dams and irrigation projects that have been constructed at the headwaters in neighboring countries such as Turkey, Iran, and Syria, where the greater part of the water flowing into the lake comes from Turkey.

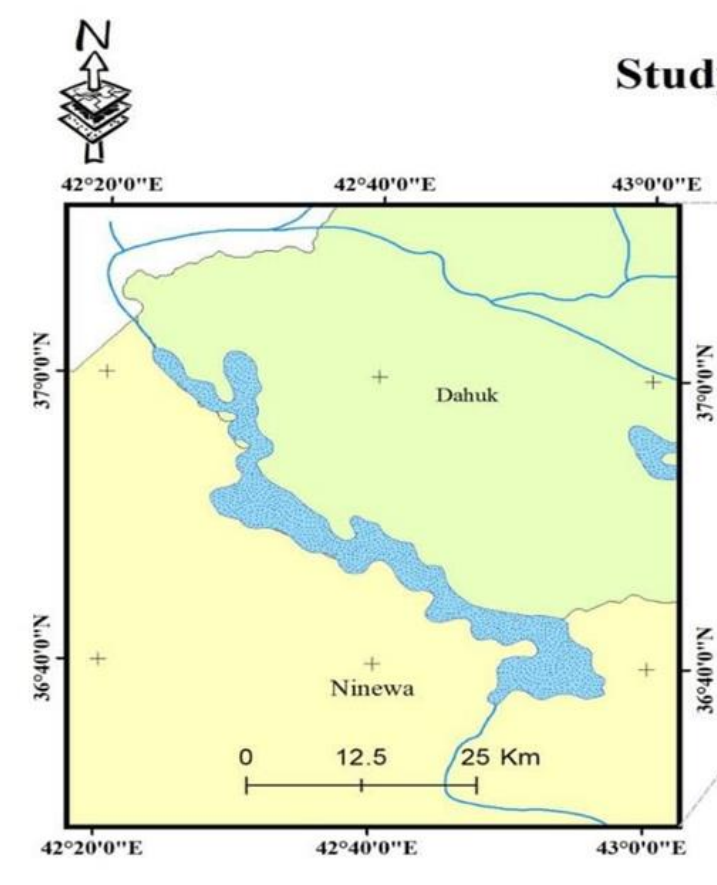

Figure 1. location of Mosul dam lake

\section{Data acquisition}

The five satellite images of series Landsat which whose path was 170 and Raw was 35 have been downloaded from The United States Geological Survey (USGS) database (11). These images were gathered and employed to give clarifications on lake surface area fluctuations for 20 years, acquired in April from $(15 / 2000)$ for Landsat 5TM, $(21 / 2005,3 / 2010$ and $14 / 2020)$ for landsat7 ETM+, and (25/2015) for landsat8 OLI sensors types with $30 \mathrm{~m}$ ground resolution and $185 \times 185 \mathrm{~km}$ ground area, the data scenes were all clear of clouds. an efficient tool, the Geographic Information System (ARC GIS10.3) program, is gathering Raw data, processing, analyzing, and presenting spatial data, also evaluate of water resources with the accurate, quick, and implemented spatial technology objectives $(6,8)$
Methodology

The following tasks were performed to obtain the objectives of the study: data collection, image pre-processing, image processing, the NDWI approach, extraction of the lake surface area in each image, differencing technique, and change detection. Figure 2 illustrates the main techniques proposed in this research to detect changes in the lake surface area.

\section{Pre-processing images}

Best and cloud-free satellite images that cover the study area, bad images, or contain defects have been excluded, so registered in the same projection system the Universal Transverse Mercator (UTM) and World Geodetic System (WGS 84).

\section{Post processing images}

Normalized difference water index (NDWI)

NDWI an easy and effective technique used to extract water bodies (15), which is calculated from two or more image bands, to identify the 
differences between water and non-water areas $(31)$. The last one and $(1,30)$ found The performance of NDWI was more accurate for different elevation ranges and water types than other indices and hence it was used to model the lake's spatial Changes. (25) A limit estimation of zero Proposed to extract water bodies from the Raw digital Landsat values, where all positive NDWI values were classified as water and negative values as nonwater. However, this limit estimation does not enable discrimination between built-up surfaces and water pixels. The NDWI for TM,
ETM+, and OLI sensors is formulated by Equations below (33):

NDWI $=\left(\mathbf{R}_{\text {Green }}-\mathbf{R}_{\text {NIR }}\right) /\left(\mathbf{R}_{\text {Green }}+\mathbf{R}_{\text {NIR }}\right)$

NDWI 5 TM,7ETM $+=(\mathrm{B} 2-\mathrm{B} 4) /(\mathrm{B} 2+\mathrm{B} 4)$

$\mathrm{NDWI}_{8 \mathrm{OLI}}=(\mathrm{B} 3-\mathrm{B} 5) /(\mathrm{B} 3+\mathrm{B} 5)$

where $\mathrm{R}_{\text {NIR }}$ and $\mathrm{R}_{\text {green }}$ are the Reflectance of the near-infrared (band 4) and the green (band2) respectively in Landsat 5TM and 7ETM+ sensors(29) .while, $\mathrm{R}$ NIR and $\mathrm{R}$ green are the Reflectance of the near-infrared (band 5) and the green (band3) consecutively in land8 OLI sensor

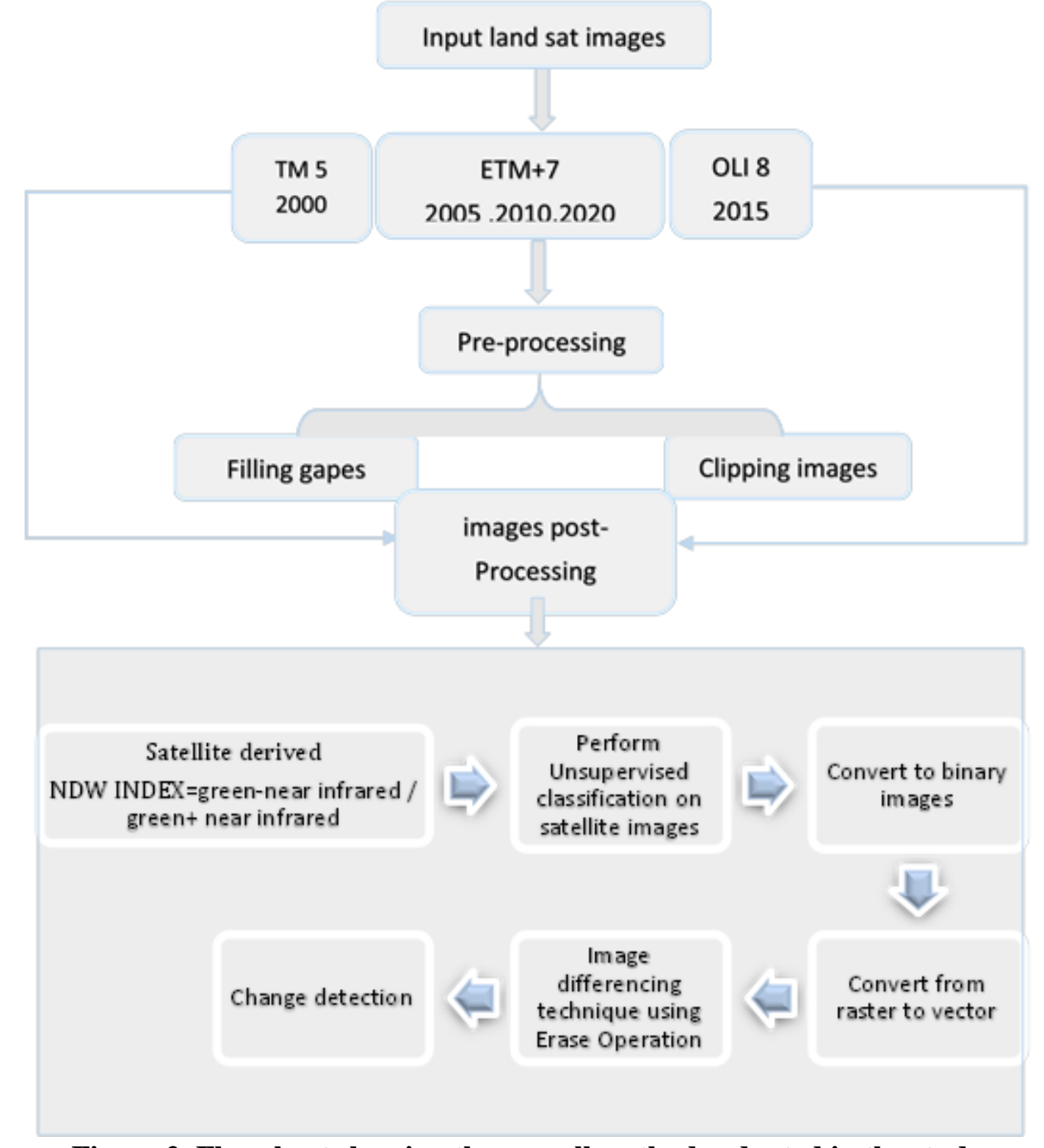

Figure 2. Flowchart showing the overall methods adopted in the study

\section{Unsupervised classification}

Unsupervised classification is The distinction between water and non-water objects, based on mixtures of two or more spectral bands using different mathematical operations, which was scientifically used to divide the data into two classes. (7).

\section{Differencing image technique}

By using the image differences technique in the ARC GIS10.3 program, can be detected 
changes in the mentioned area, subtracting pixel values to the same position as two pictures include two different periods. Pixelby-pixel comparisons are made between the two co-registered images, and pixels related to altered areas yield values distinct from those pixels followed by unchanged areas(32). Image differentiation can be mathematically represented as follows:

$\mathrm{D}_{\mathrm{I}}=\mathrm{I}(\mathrm{T} 1)-\mathrm{I}(\mathrm{T} 2)$

Where $D_{I}$ represents the difference between images and I(T1) and I(T2) represents the captured images during two different periods. the changed images have been Reclassified into three categories, The value $(1,0,-1)$ for an increase, never, and decrease change areas respectively (5).

\section{RESULTS AND DISCUSSION}

water body extraction techniques were used to determine decreasing and increasing trends of surface area in Mosul lake to a series of

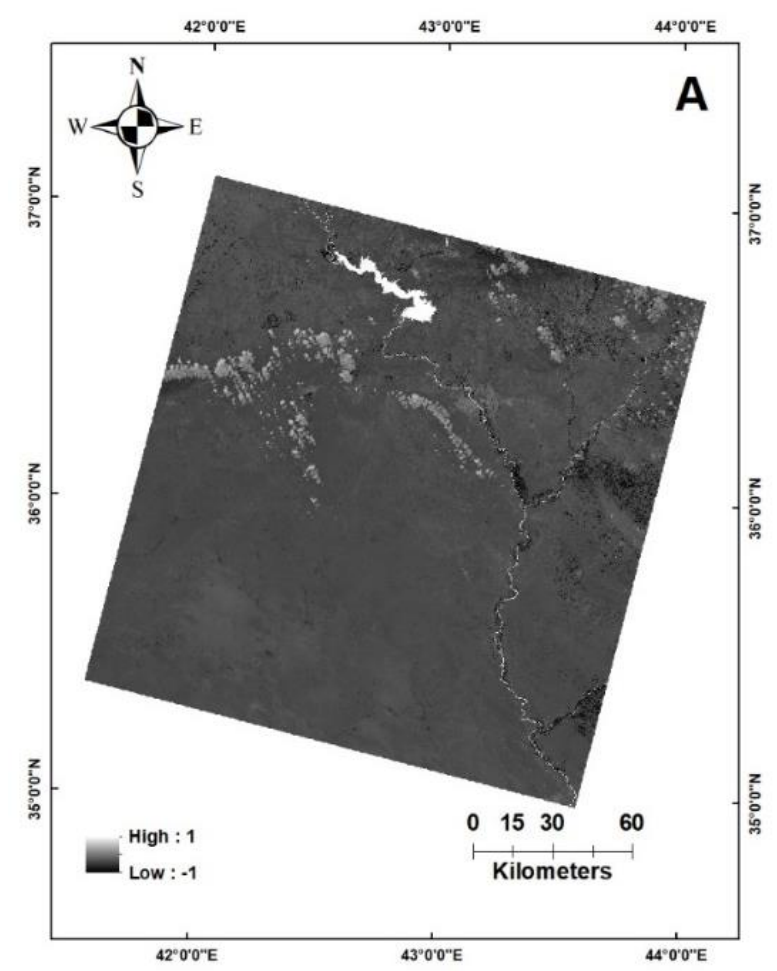

Landsat images between 2000 and 2020 when the values of NDWI ranged between $(+1$ to 1).in the present study, ArcGIS version 10.3 was applied to classify data into two classes Figure 3 and 4 due to the high reflectivity of plant and soil in the range of near-infrared makes the values of NDWI positive for the presence of water areas like (water bodies, rivers, and canals) and are enhanced therefore appear to be bright, While the green and built areas like (Vegetation, bare land) are dark and have negative values or zero and are suppressed. an unsupervised classification technique was applied on the NDWI images, to know the Spatial variation of the water bodies. As well differencing image technique has been employed to capture and detect changes in a mentioned lake. Eventually, the water surface areas of the lake are computing in $\mathrm{km}^{2}$.

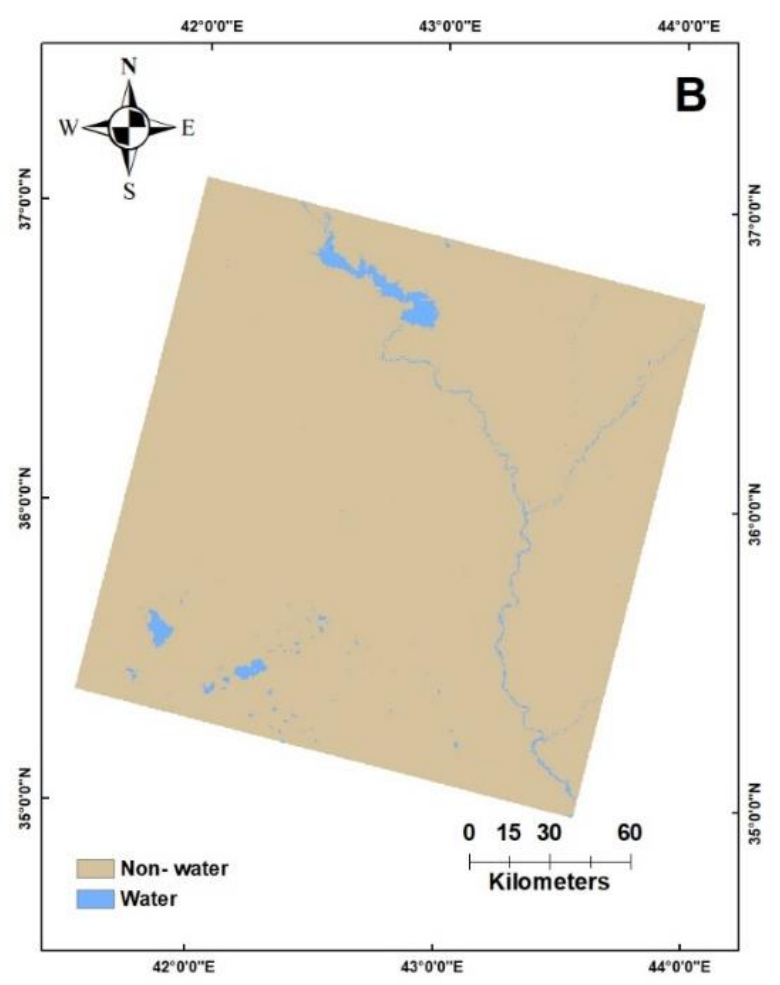

Figure 3. images represent A- NDWI images, B-unsupervised classification 

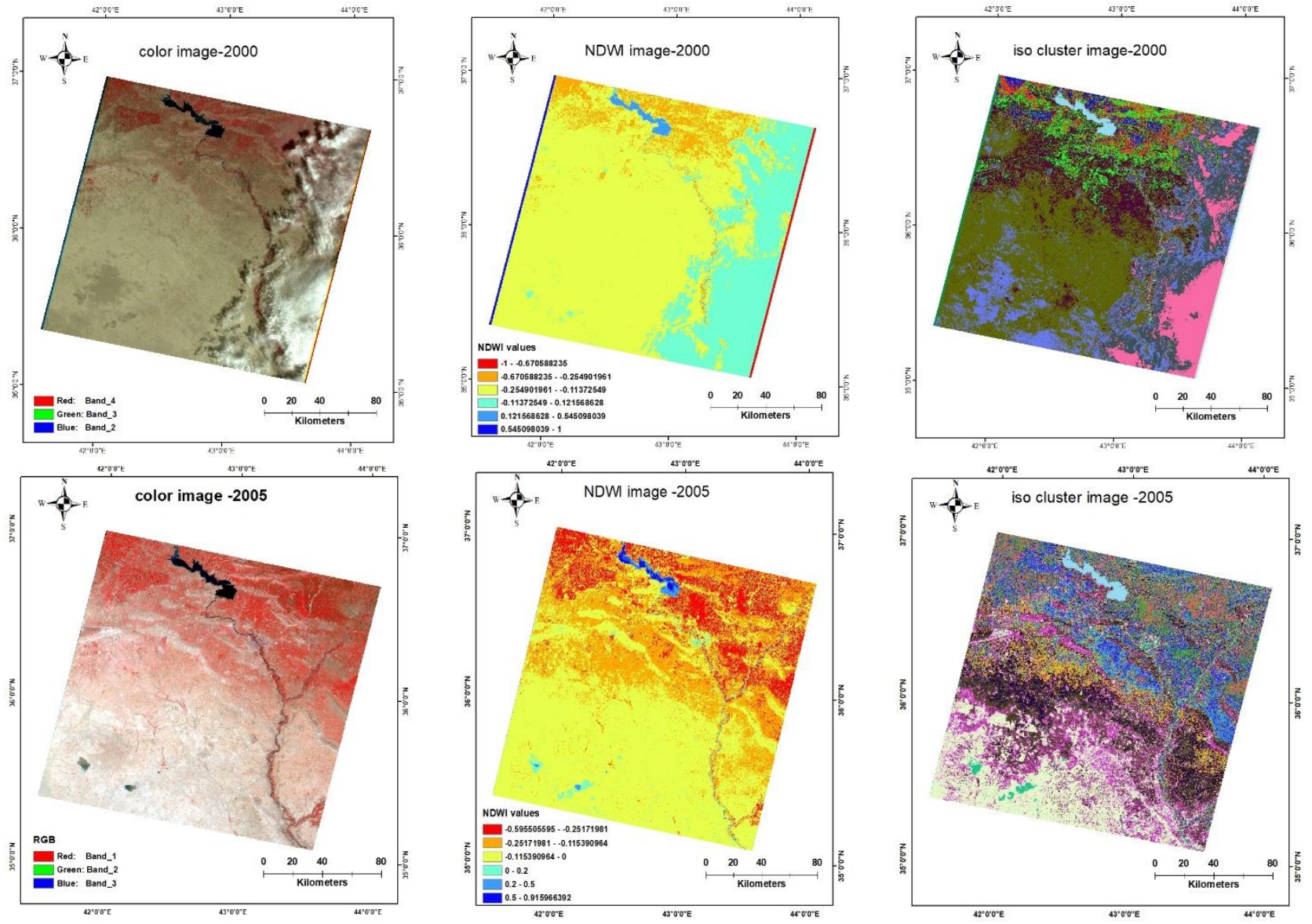

\section{Followed Figure}

Due to Previous studies, Satellite imagery and measurements obtained indicates that the total area of the lake surface had dimmed and the volume of the water reduced. The results showed in Figure 5 since 2000 the lake area was $281 \mathrm{~km}^{2}$ increase at a rate of $15.1 \%$ from its original area which was $244 \mathrm{~km} 2$ in 1986 calculated by (13) until 2005 to achieve its largest area and the most elevated rate during

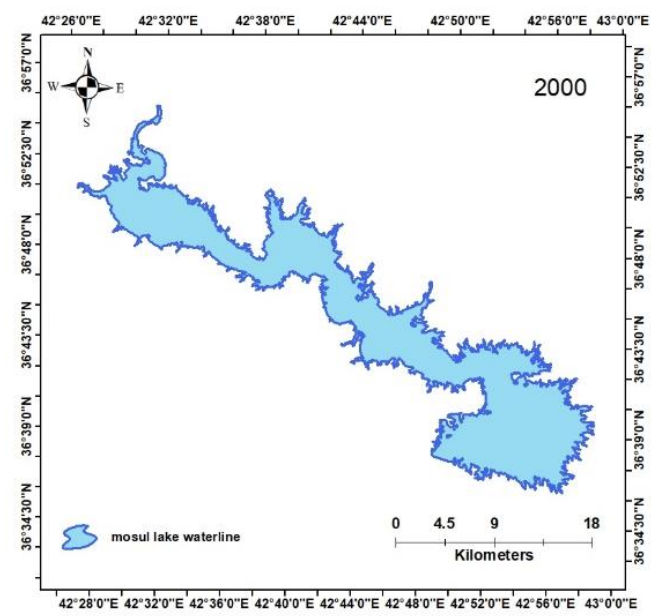

the study period $320 \mathrm{~km}^{2}$ at a rate of $31.14 \%$. However, after 2005 The lake suffered an apparent decline in its area compared to 2005, and at a rate of $7.786 \%$ from its original area to have $225 \mathrm{~km}^{2}$ in 2010 , then the lake area was increase again to reach $276 \mathrm{~km}^{2}$ and 295 $\mathrm{km}^{2}$ at a rate of $13.11 \%$ and $20.9 \%$ in 2015 and 2020 respectively. Table 1 shows the results of satellite images across two decades for the Lake in each year.

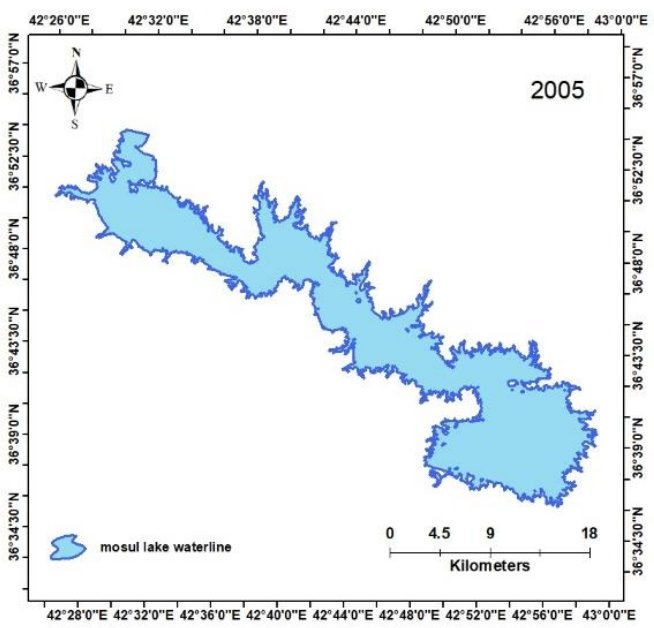



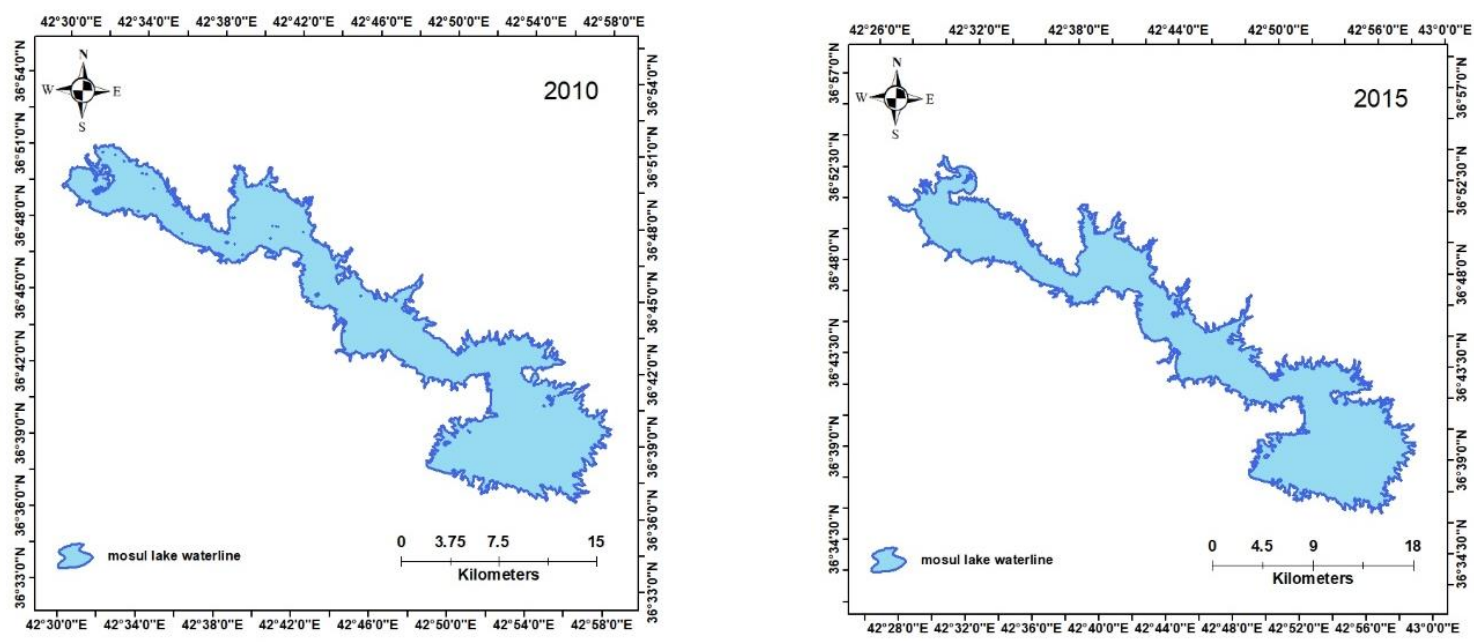

Figure 5. show binary maps for the period from 2000-20200

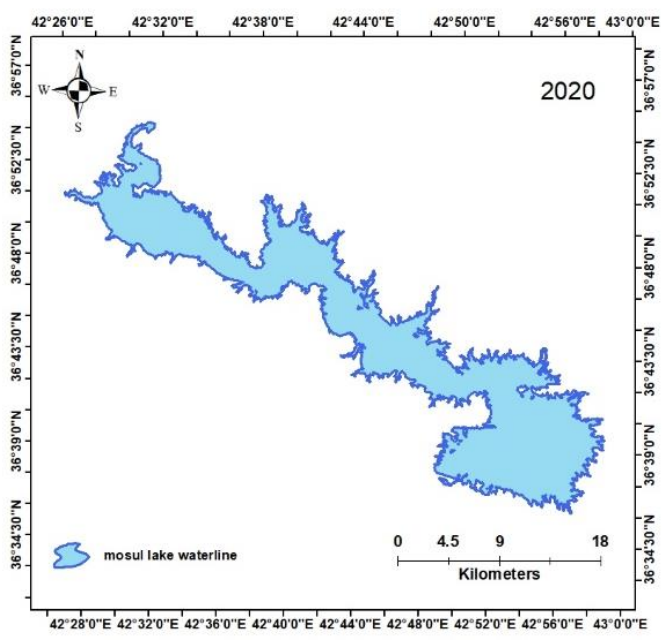

Followed Figure

Table 1. shows water surface area

\begin{tabular}{|ccc|}
\hline Year /April & Sensor type & water surface area $/ \mathbf{k m 2}$ \\
\hline 2000 & Landsat 5 TM & 281 \\
2005 & Landsat 7 ETM+ & 320 \\
2010 & Landsat 7 ETM+ & 225 \\
2015 & Landsat 8 OLI & 276 \\
2020 & Landsat 7 ETM+ & 295 \\
mean & & 279.4 \\
\hline
\end{tabular}

The results appeared in Tables 1and 2, and Figures 5and 6 verified that there was a variety in the quantity of water surface, wherein 2000 it was $281 \mathrm{~km}^{2}$ and the most elevated rate during the study period is $320 \mathrm{~km}^{2}$ in 2005 . This indicated an expansion in the amount of water surface area by about $40.297049 \mathrm{~km}^{2}$ during the period from 2000 to 2005 , stabilized the country with neighboring. It was $225 \mathrm{~km}^{2}$ in 2010, This indicated a decrease sharply in the amount of the water surface by about $94.962808 \mathrm{~km}^{2}$ during the period 2005 to 2010 . It reached $276 \mathrm{~km}^{2}$ in 2015 , which indicated that the amount of water surface increase by about $52.919903 \mathrm{~km}^{2}$ during the period from 2010 to 2015 . It reached the amount of $295 \mathrm{~km}^{2}$ in 2020 where the amount of the increase was slightly about 18.616574 $\mathrm{km}^{2}$ during the period from 2015 to 2020 , due to the amount of precipitation and water sources from neighboring countries in this period. 

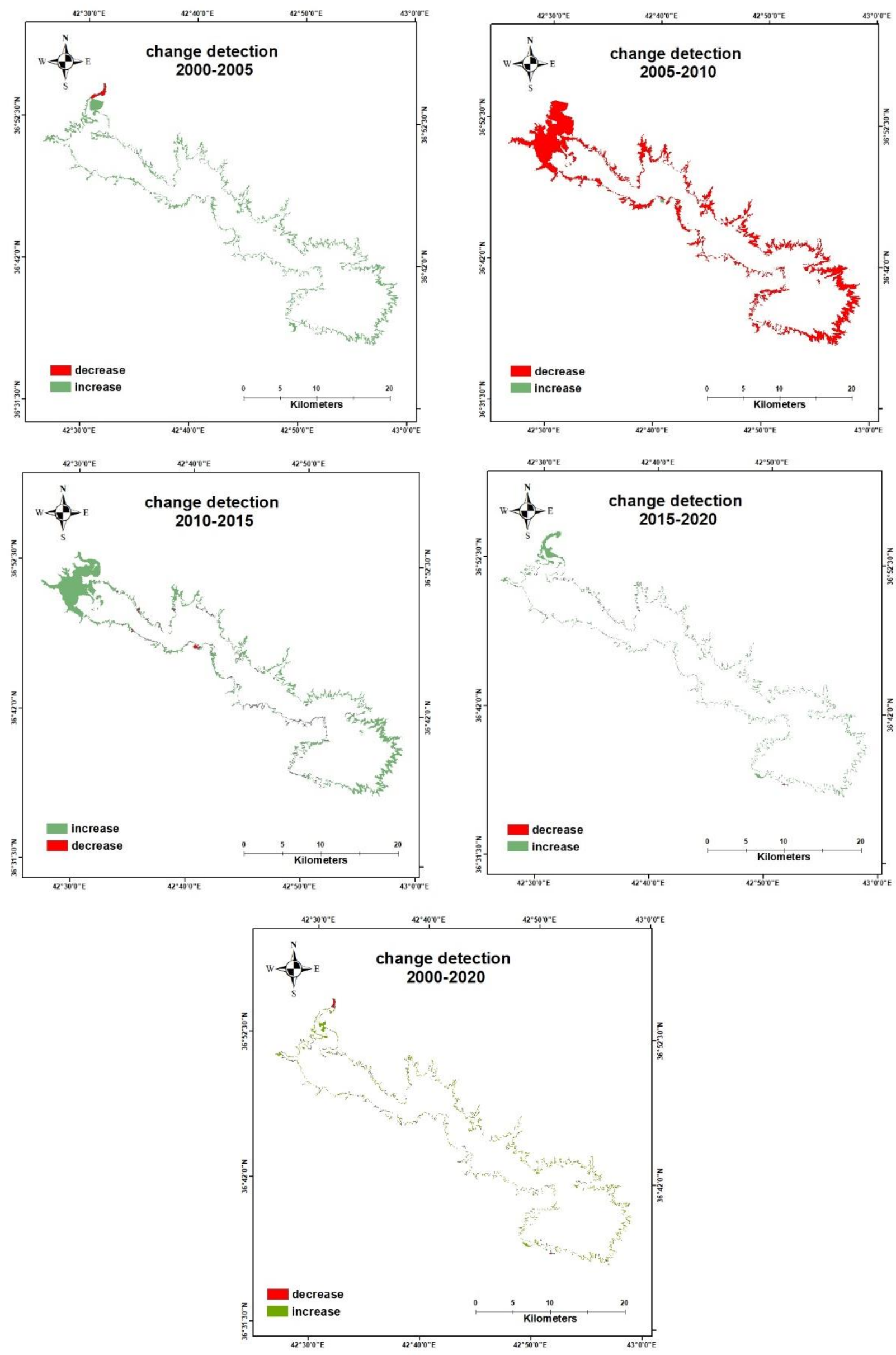

Figure 6. shows the Spatial variation of Mosul lake 
Table 2. show the increase and decrease of Mosul lake

\begin{tabular}{|ccc|}
\hline periods & Change type & Area $/ \mathbf{k m 2}$ \\
\hline $2000-2005$ & decrease & 1.234788 \\
& increase & $\mathbf{4 0 . 2 9 7 0 4 9}$ \\
$2005-2010$ & decrease & $\mathbf{9 4 . 9 6 2 8 0 8}$ \\
& increase & $\mathbf{0 . 4 4 6 9 9 5}$ \\
$2010-2015$ & decrease & 1.664588 \\
& increase & $\mathbf{5 2 . 9 1 9 9 0 3}$ \\
$2015-2020$ & decrease & $\mathbf{0 . 2 4 3 7 4 9}$ \\
& increase & $\mathbf{1 8 . 6 1 6 5 7 4}$ \\
$2000-2020$ & decrease & $\mathbf{0 . 8 1 9 9 7 9}$ \\
& increase & $\mathbf{1 4 . 9 9 4 5 6 6}$ \\
\hline
\end{tabular}

CONCLUSION: The use of remote sensing data series Landsat images (TM5, ETM+7, and OLI8) provides an efficient method for detecting changes in the quantity of water in the study area as well as low costs. By using the NDW index equation, we infer that during the periods $(2000,2005,2010,2015$, and 2020), the water body in the study area was (281, $320,225,276$, and 295) $\mathrm{Km}^{2}$ respectively. The increase and decrease are inferred From the erase operation, the expansion periods denote prior years with late years while the lessening periods represents late years with prior years, the water body in the study area through reduction periods (2000-2005),(2005-2010), (2010-2015), (2015-2020), (2000-2020) were (1.234788, (94.962808, 1.664588, 0.243749 and 0.819979$) \mathrm{km}^{2}$ respectively, and the water body area for the through increase periods (2005-2000), (2010-2005), (2015-2010), (2020- 2015),(2020-2000)were (40.297049, $0.446995, \quad 52.919903, \quad 18.616574$ and 14.994566) $\mathrm{km}^{2}$ respectively. The difference in water bodies was due to inflow and outflow water country policy, human activities, climates change, and global warming.

\section{RFEFERNCES}

1. Acharya, T. D., A. Subedi, and D. H. Lee. 2018. Evaluation of water indices for surface water extraction in a landsat 8 scene of Nepal. Sensors (Switzerland) 18: 1-15

2. Adamo, N., and N. Al-Ansari. 2016. Mosul Dam full story: Safety evaluations of Mosul Dam. J. Earth Sci. Geotech. Eng. 6: 185-212 3. Adeeb, H. Q., and Y. K. Al-Timimi. 2019. Gis techniques for mapping of wind speed over Iraq. Iraqi J. Agric. Sci. 50: 1-9

4. Al-Ansari, N. A. 2013. Management of Water Resources in Iraq: Perspectives and Prognoses. Engineering 05: 667-684

5. Al-Khakani, E. T., and S. R. Yousif. 2019. An assessment of soil salinity and vegetation cover changes for a part of An-Najaf governorate using remote sensing data. J. Phys. Conf. Ser. 1234

6. Ali, M. I., and M. R. Abidin. 2019. Population Density and Intensity of Traffic Connection: Spatial Analysis (Overlay).

7. Ali, M. I., G. D. Dirawan, A. H. Hasim, and M. R. Abidin. 2019. Detection of changes in surface water bodies urban area with NDWI and MNDWI methods. Int. J. Adv. Sci. Eng. Inf. Technol. 9: 946-951

8. Ali, M. I., and M. Rais. 2018. Spatial Pattern of Crime with Geographic Information System (GIS) in Makassar, Indonesia

9. Amtair Rahi, K. 2018. Salinity Management in the Shatt Al-Arab River. Int. J. Eng. Technol. 7: 128

10. El-Asmar, H. M., and M. E. Hereher. 2011. Change detection of the coastal zone east of the Nile Delta using remote sensing. Environ. Earth Sci. 62: 769-777

11. Explorer, U. E. 1879. The United States Geological Survey (USGS, formerly simply Geological Survey) is a scientific agency of the United States government. Virginia, United States pp:10-65

12. Feyisa, G. L., H. Meilby, R. Fensholt, and S. R. Proud. 2014. Automated Water Extraction Index: A new technique for surface water mapping using Landsat imagery. Remote Sens. Environ. 140: 23-35

13. H, M. M., I. S. Abbood, S. E. Diwan, and A. N. Hanoon. 2020. Surface area evalution of Mosul Dam Lake using satellite imagery technique. 6: 85-100

14. Hereher, H. M. E. M. E. 2011. Change detection of the coastal zone east of the Nile Delta using remote sensing. 769-777

15. Huang, C., Y. Chen, S. Zhang, and J. Wu. 2018. Detecting, extracting, and monitoring surface water from space using optical sensors: A Review. Rev. Geophys. 56: 333-360 
16. Issa, I. E. 2011. Dectoral thesis Sedimentological and Hydrological Investigation of Mosul Dam Reservoir Issa Elias Issa pp:17-206

17. Issa, I. E., N. Al-Ansari, and S. Knutsson. 2014. Mosul Dam Resorvoir Sedimentation Characteristics, Iraq. J. Environ. Hydrol.p: 22

18. Issa, I. E., N. Al-Ansari, S. Knutsson, and G. Sherwany. 2015. Monitoring and evaluating the sedimentation process in Mosul Dam Reservoir using trap efficiency approaches. Engineering 7: 190-202

19. Jawad, T. K., O. T. Al-Taai, and Y. K. AlTimimi. 2018. Evaluation of drought in Iraq using DSI. by remote sensing. Iraqi J. Agric. Sci. 49: 1132-1145

20. Ji, L., X. Geng, K. Sun, Y. Zhao, and P. Gong. 2015. Target Detection Method for Water Mapping Using Landsat 8 OLI/TIRS Imagery. 794-817

21. Karpatne, A., A. Khandelwal, X. Chen, V. Mithal, J. Faghmous, and V. Kumar. 2016. Global Monitoring of Inland Water Dynamics: State-of-the-Art, Challenges, and Opportunities. In: Computational Sustainability. Springer. pp. 121-147

22. Khattab, M. F. O., R. K. Abo, S. W. Almuqdadi, and B. J. Merkel. 2017. Generate Reservoir Depths Mapping by Using Digital Elevation Model: A Case Study of Mosul Dam Lake, Northern Iraq.PP: 161-174

23. Li, W., Z. Du, F. Ling, D. Zhou, H. Wang, Y. Gui, B. Sun, and X. Zhang. 2013. A comparison of land surface water mapping using the normalized difference water index from TM, ETM+ and ALI. Remote Sens. 5: 5530-5549

24. Mahmod H., M., I. S. Abbood, and A. N. Hanoon. 2020. Surface area evaluation of Mosul Dam Lake using satellite imagery Technique. matter Int. J. Sci. Technol. 6: 85100

25. McFeeters, S. K. 1996. The use of the normalized difference water index (NDWI) in the delineation of open water features. Int. J. Remote Sens. 17: 1425-1432

26. Mohammed, Y. T. 2001. Evaluation of Sediment Accumulation at the Intakes of the Main Pumping Station of North Al-Jazira Irrigation Project
27. Nasrat Adamo, Nadhir Al-Ansari, Varoujan Sissakian, Jan Laue, and Sven Knutsson. 2019. Mosul Dam: Geology and Safety Concerns. J. Civ. Eng. Archit. 13: 151177

28. Khattab.O, M. F., R. K. Abo, S. W. AlMuqdadi, and B. J. Merkel. 2017. Generate reservoir depths mapping by using digital elevation model: A Case Study of Mosul Dam Lake, Northern Iraq. Adv. Remote Sens. 06: 161-174

29. Rogers, A. S., and M. S. Kearney. 2004. Reducing signature variability in unmixing coastal marsh Thematic Mapper scenes using spectral indices. Int. J. Remote Sens. 25: 2317-2335

30. Rokni, K., A. Ahmad, A. Selamat, and S. Hazini. 2014. Water feature extraction and change detection using multitemporal landsat imagery. Remote Sens. 6: 4173-4189

31. Sarp, G., and M. Ozcelik. 2017. Water body extraction and change detection using time series: A case study of Lake Burdur, Turkey. J. Taibah Univ. Sci. 11: 381-391

32. Tan, M., and M. Hao. 2017. Change detection by using advanteges of threshold and clustering methods. Int. Arch. Photogramm. Remote Sens. Spat. Inf. Sci. 42

33. Verpoorter, C., T. Kutser, and L. Tranvik. 2012. Automated mapping of water bodies using Landsat multispectral data. Limnol. Oceanogr. Methods 10: 1037-1050

34. Williams, P. B., D. Ph, E. Ing, S. B. Frucht, and P. Williams. 2006. A Review of the hydrological and geomorphic impacts of the proposed ilisu dam Commissioned by World Economy, Ecology and Development (WEED ) on behalf of the European Ilisu Campaign: Berne Declaration Forests and the European Union Resource Network FER.pp:2-47

35. Xu, H. 2006. Modification of normalised difference water index ( NDWI) to enhance open water features in remotely sensed imagery. 27: 3025-3033

36. Yaseen, A., M. I. Mahmood, G. Yaseen, A. A. Ali, M. H. Mahmod, and A. H. Mustafa. 2018. Area change monitoring of Dokan \& Darbandikhan Iraqi Lakes Using Satellite Data. Sustain. Resour. Manag. J. 3: 25-41. 